\title{
Larval abundance variation of Bregmaceros cantori Milliken \& Houde, 1984, related to the El Niño events (1987-1996), southern Gulf of Mexico
}

\author{
Variación de la abundancia de larvas de Bregmaceros cantori Milliken \& Houde, 1984, relacionada \\ con los eventos de El Niño (1987-1996), sur del Golfo de México
César Flores-Coto ${ }^{1}$, Faustino Zavala-García ${ }^{1}$, Rene Funes-Rodríguez ${ }^{2}$, María de la Luz Espinosa-Fuentes ${ }^{1}$ and Jorge Zavala-Hidalgo ${ }^{3}$ \\ ${ }^{1}$ Universidad Nacional Autónoma de México. Instituto de Ciencias del Mar y Limnología. Laboratorio de Zooplancton. \\ A. P. 70-305, 04510 México, D. F. México \\ ${ }^{2}$ Instituto Politécnico Nacional. Centro Interdisciplinario de Ciencias Marinas, La Paz, Baja California Sur, México 04960 \\ ${ }^{3}$ Universidad Nacional Autónoma de México. Centro de Ciencias de la Atmósfera, 04510 México, D. F. México \\ coto@icmyl.unam.mx
}

\begin{abstract}
Resumen.- Se analiza la influencia de El Niño Oscilación del Sur (ENSO) sobre la variación de la abundancia de las larvas del pez Bregmaceros cantori en el sur del Golfo de México. El estudio se desarrolló entre 1987 y 1996, usando 20 cruceros oceanográficos. La abundancia de $B$. cantori fue relacionada con: (1) la anomalía de la temperatura superficial del mar (SSTA) del Océano Pacífico central ecuatorial, (2) la temperatura promedio de la capa superficial de $30 \mathrm{~m}$, de datos de las campañas, (3) las descargas de aguas continentales con datos provenientes de la estación hidrológica mas cercana al área de estudio. Hubo una alta variabilidad de la abundancia de larvas de $B$. cantori a través del tiempo, pero no se registró un patrón estacional. Durante el periodo de estudio ocurrieron tres eventos de El Niño: 1987, 1992 y 1995. Los análisis estadísticos indicaron diferencias significativas en la abundancia de larvas entre los años de El Niño y años normales, sin el evento de El Niño. Se encontraron altas abundancias de B. cantori en los periodos de El Niño en comparación con los años normales. Es posible que las mayores abundancias de larvas de $B$. cantori durante años de El Niño estén asociadas con relaciones depredador-presa.
\end{abstract}

Palabras clave: Larvas de peces, ENSO, influencia medio ambiental

\begin{abstract}
The influence of the El Niño Southern Oscillation (ENSO) on the abundance variation of fish larvae of Bregmaceros cantori in the southern Gulf of Mexico was analyzed. The study was conducted between 1987 and 1996, using 20 oceanographic cruises. The larval abundance of $B$. cantori was related to: (1) the sea surface temperature anomaly (SSTA) in the central equatorial Pacific Ocean; (2) the average temperature surface layer, to $30 \mathrm{~m}$, obtained from cruises data; (3) the continental water discharges data from the continental hydrological station nearest to the study area. The variability of $B$. cantori larval abundance was high throughout the sampling period and no seasonal pattern was detected. During the study period, three events of El Niño occurred: in 1987, 1992 and 1995. Statistical analyses indicated significant differences of the larvae abundance of $B$. cantori between El Niño and normal years, i.e, years without El Niño. High abundances of fish larvae were found during El Niño years. Higher abundances of B. cantori larvae, during El Niño years, are possibly associated to predator-prey relationships.
\end{abstract}

Key word: Larval fish, ENSO, environmental influence

\section{Introduction}

The ocean-atmosphere interaction in the central Pacific Ocean generates changes on the sea surface temperature (SST) and the movements of warm water masses, over the Ecuador-Peru-Chile coast. This phenomenon is called El Niño (Philander 1990, Chavez et al. 1999, Schwing et al. 2002), and this event together with the Southern Oscillation is called ENSO. The ENSO signals influence directly physical and biological aspects in the Pacific
Ocean, or indirectly in the Atlantic Ocean and Gulf of Mexico by atmospheric teleconnections (Lluch-Cota et al. 2004).

Among other effects, El Niño is associated with low fisheries catch in the eastern Pacific coast because this coast is in a zone with direct influence of warm waters during El Niño; for example, in Peru, fisheries decreased $60 \%$ during the 1997-1998 El Niño event (Duffy \& Bryant 1998). During the same period, in the Mexican Pacific 
coast, many fisheries resources from Sinaloa to Baja California also decreased (Lluch-Cota et al. 2004). Moreover, El Niño event also produced seasonal changes in the abundance and distribution of fishes and their spawning (Bailey \& Incze 1985, Miller et al. 1985, Smith 1985, Moser et al. 1987, MacCall \& Prager 1988); the zooplankton biomass is affected by this event along the California and Oregon coasts (Chelton et al. 1982, Roesler \& Chelton 1987). In fact, an increased number of equatorial fish larvae has also been recorded in unusual northern zones, while populations of temperate taxa contracted northward during El Niño (Moser et al. 1987, Funes-Rodríguez et al. 2002).

Mostly, the El Niño effects have been related to the fisheries in the Pacific Ocean; to our knowledge, no studies examining fisheries effects on planktonic organisms in the Gulf of Mexico have been published.

The Bregmacerotidae is among the ten more common and abundant families of organisms collected from plankton samplings, between neritic and oceanic waters, and tropical and subtropical areas (Houde 1984). In the southern Gulf of Mexico, the only genus of this fish family is Bregmaceros in which $B$. cantori is generally one of the most abundant species among other groups, such as, clupeids, engraulids, gobids and carangids (Flores-Coto et al. 1993, 2000, Espinosa-Fuentes \& Flores-Coto 2004).

Fish larvae of bregmacerotids are not commercial species, and because of their high abundance in the southern Gulf of México, they are potential markers of the effects of El Niño events.

Larval abundance variation of $B$. cantori in the Gulf of Mexico has no evident seasonal patterns (Houde 1981, Zavala-García \& Flores-Coto 1994), and the abundance variability may be caused by El Niño event. Thus, the objective of this study was to determine if there was a relationship between the larval abundance of $B$. cantori and some environmental factors associated with the El Niño phenomenon.

\section{Material and methods}

\section{Data collection}

The Bregmacerotidae larvae used in this study were collected during 20 oceanographic cruises. From the winter, between 1992 and 1996, 16 seasonal cruises over 22 sampling stations distributed in four transects on the continental shelf of the southern Gulf of Mexico were performed (Fig. 1). A series of another four cruises were carried out, three in 1987, and one in summer 1988.

During 1987, 1988, 1992, and spring of 1993, Bongo

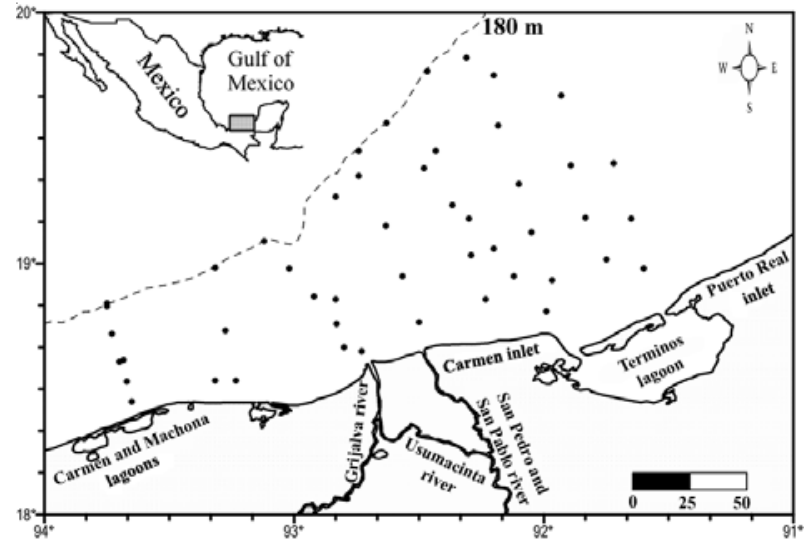

Figure 1

\section{Study area and sampling stations in the southern} Gulf of Mexico

Área de estudio y estaciones de muestreo en el sur del Golfo de México

nets with double-oblique tows were used while other cruises used open-close nets with stratified sampling in the water column. In all cases, the mesh size was $505 \mu \mathrm{m}$; the samples were preserved in formalin $4 \%$ and then transferred to alcohol $70 \%$ after $24 \mathrm{~h}$.

Local temperature data were obtained using a conductivity temperature depth (CTD) instrument (except in four cruises) and an average of $30 \mathrm{~m}$ surface layer by cruise was considered for this study.

\section{Data analysis}

All fish larvae were extracted from the sample and those of the Bregmacerotidae family were selected. Species were identified according to Richards (2006) and their densities were expressed as number of organisms per $100 \mathrm{~m}^{3}$.

Monthly sea surface temperature anomalies (SSTA) data of the central equatorial Pacific Ocean (Region 3.4) were obtained from the Climate Prediction Center of the National Oceanic and Atmospheric Administration (NOAA) (Table 1).

Continental water discharge data were taken from the hydrological station nearest to the Grijalva-Usumacinta outlet (Table 1).

Monthly mean wind data for the period 1970-2002 were used for the wind field analysis. To estimate the convergence of the wind component along the coast, this quantity was computed along the segments between $21^{\circ} \mathrm{N}$ and $20^{\circ} \mathrm{N}$ on the eastern side of the Bay of Campeche as well as between $19 \mathrm{~N}$ and $20^{\circ} 30^{\prime} \mathrm{N}$ on the western side. The difference was evaluated for each month and the 
Table 1

Data source of the variables analyzed in this study, during several time periods

Fuente de los datos de las variables analizadas en este estudio, durante varios períodos de tiempo

\begin{tabular}{|c|c|c|}
\hline Variables & Period & Source \\
\hline \multirow{2}{*}{$\begin{array}{l}\text { Sea surface temperature } \\
\text { anomalies (SSTA) }\end{array}$} & \multirow[t]{2}{*}{$1987-1996$} & Climate Prediction Center \\
\hline & & http://www.cpc.ncep.noaa.gov/data/indices/ \\
\hline Continental Water Discharges & $1987-1996$ & $\begin{array}{l}\text { Banco Nacional de Datos de Aguas Superficiales } \\
\text { (BANDAS) CNA-IMTA (México) }\end{array}$ \\
\hline Wind Fields Anomalies & $1970-2002$ & http://data.ecmwt.imt/data \\
\hline Chlorophyll Anomalies & $1997-2004$ & $\begin{array}{c}\text { SeaWiFS level } 3 \text { Standard Mapped Images Goddard } \\
\text { Distributed Active Archive Center at the } \\
\text { NASA/Goddard Space Flight Center }\end{array}$ \\
\hline
\end{tabular}

anomaly was computed by subtracting the monthly mean of the mentioned period (Table 1).

The monthly anomaly of chlorophyll $a$ concentration (as indicator of productivity) was computed by subtracting the corresponding monthly mean of the period to the value of each month. Then, the values of the shelf in the area of study and those of the southern site of the Bay of Campeche were selected for analysis. Montly satellite data used for this study were chlorophyll and climatology data, from September 1997 to December 2004. Eight years of Sea-viewing Wide Field-of-view Sensor (SeaWiFS) ocean color images were also analyzed (Table 1). Further information regarding the calibration methodologies and SeaWiFS data processing can be found in McClain et al. (1998).

\section{Statistical analysis}

To estimate if there were significant differences among seasonal larval densities, a Kruskal-Wallis multiple comparison test was applied. To obtain the association between the SSTA and larval density, a Spearman correlation test was used, using the larval average density of each season (equals each cruise) and the corresponding SSTA average. The relationships of these variables were calculated and compared between years when El Niño event occurred and for normal years (without El Niño). Finally, the same data were analyzed yearly. Spearman correlations were also used to relate the larval density means to local temperature and continental water discharge. The Chi-square test was used to establish if there was a difference between the annual average larval densities (Zar 1996). The observed values (Ni) of annual catches correspond to the natural logarithm of the annual average density plus one. The expected values (Ei) for each year were obtained using: $\mathrm{Ei}=\sum \mathrm{Ni}\left(\mathrm{Ai} / \sum \mathrm{Ai}\right)$, where $\mathrm{Ai}=$ SSTA annual average plus two.
Several environmental factors were identified as likely related to or influenced by El Niño conditions: local water temperature, continental water discharges, wind field anomaly and chlorophyll anomaly (see Table 1 for data sources). The relationships between these environmental variables and SSTA were determined through Pearson correlations. In addition, the relationship between wind field anomaly and chlorophyll anomaly was also tested using a Pearson correlation.

\section{Results}

\section{Abundance pattern}

Four species, Bregmaceros cantori Milliken \& Houde, 1984, B. atlanticus Good \& Bean, 1886, B. houdei Saksena \& Richards, 1986 and Bregmaceros n. sp, have been recorded in the study area; $B$. cantori was the more abundant (98.5\%), B. atlanticus was scarce (1.37\%), while the other two species were rare.

A large variability of larval abundance of $B$. cantori was observed (Table 2, Fig. 2) and no seasonal pattern was detected. Higher and lower larval densities occurred in different seasons and different years. For instance, high densities were recorded during the summer and fall of 1987, or the winter of 1992 and 1995 (Fig. 2). The Kruskal-Wallis test showed no significant differences among seasonal densities $(P>0.05)$ (Table 3$)$.

\section{El Niño and abundance variability of Bregmaceros cantori larvae}

The periods of high and low B. cantori larval abundance corresponded to El Niño and normal years, respectively (Fig. 2). The Spearman correlation, using the total data as independent of the year or season between SSTA and larval abundance, showed positive relationship although it was not significant (Table 3). The larval abundance 
Table 2

Seasonal average density of Bregmaceros cantori larvae (in $100 \mathrm{~m}^{3}$ ) in the southern Gulf of Mexico between 1987 and 1996

Densidad promedio estacional de larvas de Bregmaceros cantori (en $100 \mathrm{~m}^{3}$ ) en el sur del Golfo de México entre 1987 y 1996

\begin{tabular}{ccc}
\hline Year & Season & B. cantori \\
\hline \multirow{3}{*}{1987} & Winter & 4.597 \\
& Summer & 57.419 \\
& Fall & 28.475 \\
\hline 1988 & Summer & 11.857 \\
\hline & Winter & 18.124 \\
1992 & Spring & 14.470 \\
& Summer & 13.880 \\
& Fall & 7.955 \\
\hline & Winter & 2.885 \\
1993 & Spring & 4.910 \\
& Summer & 8.029 \\
& Fall & 2.085 \\
\hline \multirow{3}{*}{1994} & Spring & 1.564 \\
& Summer & 1.113 \\
& Fall & 1.822 \\
\hline \multirow{3}{*}{1995} & Winter & 14.756 \\
& Spring & 2.719 \\
& Summer & 12.244 \\
& Fall & 6.435 \\
\hline 1996 & Winter & 9.447 \\
\hline \multirow{3}{*}{$\Sigma$} & & $\mathbf{2 2 4 . 7 8 5 8}$ \\
\hline & r
\end{tabular}

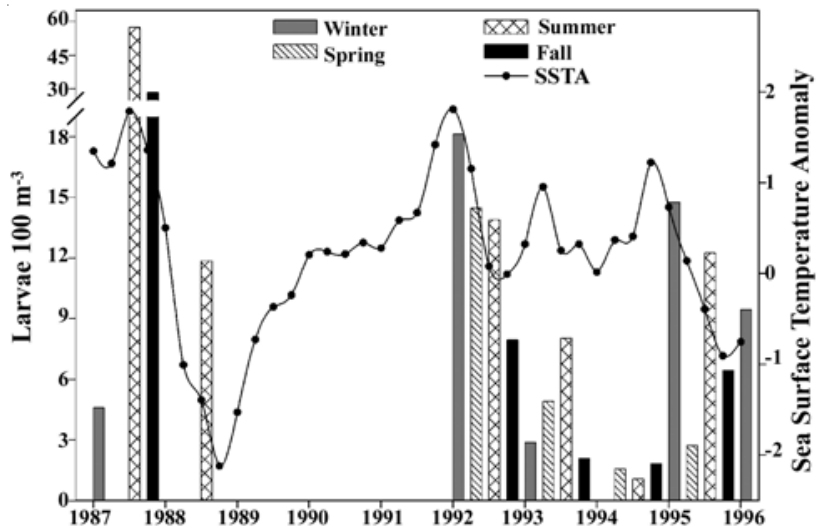

Figure 2

Seasonal variation of Bregmaceros cantori larval abundance related to the sea surface temperature anomaly in the central equatorial Pacific, Region Niño 3.4

Variación estacional de la abundancia de las larvas de Bregmaceros cantori relacionada con la anomalía de la temperatura superficial del mar en el Océano Pacífico ecuatorial central, Región Niño 3.4 and SSTA showed a positive and significant correlation during El Niño years $(1987,1992,1995)\left(r_{s}=0.63\right)$ and a negative but no significant correlation during normal years $(1993,1994)\left(r_{s}=-0.39\right)$.

Analyses performed by years showed a significant positive correlation for El Niño 1987 and $1992\left(r_{s}=1\right)$, and a not significant correlation in $1995\left(r_{s}=0.40\right)$; and for normal years, a negative correlation in $1993\left(\mathrm{r}_{\mathrm{s}}=-0.40\right)$ and positive correlation in $1994\left(\mathrm{r}_{\mathrm{s}}=0.5\right)$ (Table 3).

Results of the Chi-square test indicated significant differences among annual average larval density ( $\alpha=$ $0.05, \mathrm{df}=4$ ) and the residual standard values corroborated a higher larval abundance of $B$. cantori during El Niño

Table 3

Results of statistical analyses applied to different variables

Resultados de los análisis estadísticos aplicados a las diferentes variables

\begin{tabular}{|c|c|c|c|c|}
\hline Test & Variables & $\begin{array}{l}\text { Test Statistic } \\
\text { Value }\end{array}$ & $P$-value & $\mathrm{N}$ \\
\hline Kruskal Wallis & Larval Density - Season & 2.08 & 0.56 & 20 \\
\hline Spearman & $\begin{array}{l}\text { Larval Density - SSTA } \\
\text { (All years) }\end{array}$ & 0.29 & 0.23 & 18 \\
\hline Spearman & $\begin{array}{l}\text { Larval Density - SSTA } \\
\text { (Niño years) }\end{array}$ & 0.63 & $0.04^{*}$ & $11 \mathrm{~s}$ \\
\hline Spearman & $\begin{array}{l}\text { Larval Density - SSTA } \\
\text { (Non Nifio years) }\end{array}$ & -0.39 & 0.34 & 7 \\
\hline Spearman & $\begin{array}{l}\text { Larval Density - SSTA } \\
\text { (1987) }\end{array}$ & 1.00 & $0.00^{*}$ & 3 \\
\hline Spearman & $\begin{array}{c}\text { Larval Density - SSTA } \\
\text { (1992) }\end{array}$ & 1.00 & $0.00^{*}$ & 4 \\
\hline Spearman & $\begin{array}{l}\text { Larval Density - SSTA } \\
\text { (1993) }\end{array}$ & -0.40 & 0.49 & 4 \\
\hline Spearman & $\begin{array}{c}\text { Larval Density -. SSTA } \\
\text { (1994) }\end{array}$ & 0.50 & 0.48 & 3 \\
\hline Spearman & $\begin{array}{c}\text { Larval Density - SSTA } \\
\text { (1995) }\end{array}$ & 0.40 & 0.49 & 4 \\
\hline Chi-square & $\begin{array}{l}\text { Annual Larval Density and } \\
\text { SSTA }\end{array}$ & 1.21 & $0.05^{*}$ & 5 \\
\hline Spearman & $\begin{array}{c}\text { Larval Density - Local } \\
\text { Temperature }\end{array}$ & -0.19 & 0.45 & 18 \\
\hline Spearman & $\begin{array}{c}\text { Larval Density - } \\
\text { Continental Discharge }\end{array}$ & -0.17 & 0.50 & 18 \\
\hline Pearson & SSTA - Local Temperature & -0.07 & 0.80 & 17 \\
\hline Pearson & $\begin{array}{l}\text { SSTA - Continental } \\
\text { Discharge }\end{array}$ & -0.62 & $0.02 *$ & 13 \\
\hline Pearson & $\begin{array}{l}\text { SSTA - Wind Field } \\
\text { Anomaly }\end{array}$ & 0.91 & $0.00^{*}$ & 33 \\
\hline Pearson & $\begin{array}{l}\text { Wind Field Anomaly - } \\
\text { Chlorophyll Anomaly }\end{array}$ & -0.14 & 0.42 & 33 \\
\hline Pearson & $\begin{array}{c}\text { SSTA - Chlorophyll } \\
\text { Anomaly }\end{array}$ & -0.17 & 0.36 & 33 \\
\hline
\end{tabular}

* Significant difference 
1987, 1992, and 1995 than normal years 1993 and 1994 (Tables 3 and 4).

\section{Environmental factors and larval abundance}

Results showed a relationship between the high larval abundance of $B$. cantori and the El Niño years. To investigate what factors were influencing the larval abundance variability, the following factors were considered: local temperature, continental water discharges, chlorophyll (as indicator of productivity).

It was found a negative correlation between larval density and local temperature $\left(r_{\mathrm{s}}=-0.19\right)$ and continental water discharges $\left(r_{s}=-0.17\right)$ (Table 3). There was also an inverse relationship between SSTA and local water temperature (Table 3, Fig. 3A) and continental water discharges (Table 3, Fig. 3B). In the latter, the inverse relationship with SSTA was more evident and statistically significant.

There was a high and significant relationship between SSTA and wind fields anomalies (WFA) $(r=0.91)$. The chlorophyll anomaly also had a negative relationship with WFA $(r=-0.14)$ and SSTA $(r=-0.17)$ (Table 3, Fig. 4).

\section{Table 4}

Chi square $\left(\chi^{2}\right)$ analysis of the abundance of Bregmaceros cantori larvae among years $(\alpha=0.05, \mathrm{df}=4)$. SSTA $=$

Annual average of the sea surface temperature anomaly on the central equatorial Pacific Ocean (Region 3.4). $\mathrm{D}=$ Annual average larval density. $\mathrm{Ni}=\operatorname{Ln}(\mathrm{D}+1) . \mathrm{Ei}=$ Expected values. $\mathrm{SRi}=$ Standardized residual

Análisis de Chi cuadrado $\left(\chi^{2}\right)$ de la abundancia de larvas Bregmaceros cantori entre años $(\alpha=0,05, \mathrm{df}=4)$. SSTA $=$ Promedio anual de la anomalía de la temperatura superficial del mar en el Océano Pacífico ecuatorial central (Región 3.4). $\mathrm{D}=$ Promedio anual de la densidad larval. $\mathrm{Ni}=\mathrm{Ln}(\mathrm{D}$

+1). $\mathrm{Ei}=$ Valores esperados. $\mathrm{SRi}=$ Valores de residual estandarizado

\begin{tabular}{cccccc}
\hline \multicolumn{7}{c}{ ear } & SSTA+2 & $\begin{array}{c}\mathrm{D} \\
\left(\text { Org } 100 \mathrm{~m}^{-3}\right)\end{array}$ & $\begin{array}{c}\mathrm{Ni}(\mathrm{D}+1) \\
\text { Ln }\end{array}$ & $\mathrm{Ei}$ & $\mathrm{SRi}$ \\
\hline 87 & 3.43 & 31.29 & 3.47 & 2.91 & 0.33 \\
92 & 2.75 & 13.60 & 2.68 & 2.33 & 0.23 \\
93 & 2.47 & 4.57 & 1.72 & 2.10 & -0.26 \\
94 & 2.50 & 1.51 & 0.92 & 2.13 & -0.83 \\
95 & 1.90 & 8.76 & 2.28 & 1.60 & 0.53 \\
\hline$\Sigma$ & $\mathbf{1 3 . 0 4}$ & $\mathbf{5 9 . 7 2}$ & $\mathbf{1 1 . 0 7}$ & $\mathbf{1 1 . 0 7}$ \\
\hline$\chi^{2}$ & & & & & $\mathbf{1 . 2 1 *}$ \\
\hline
\end{tabular}

* Significant difference
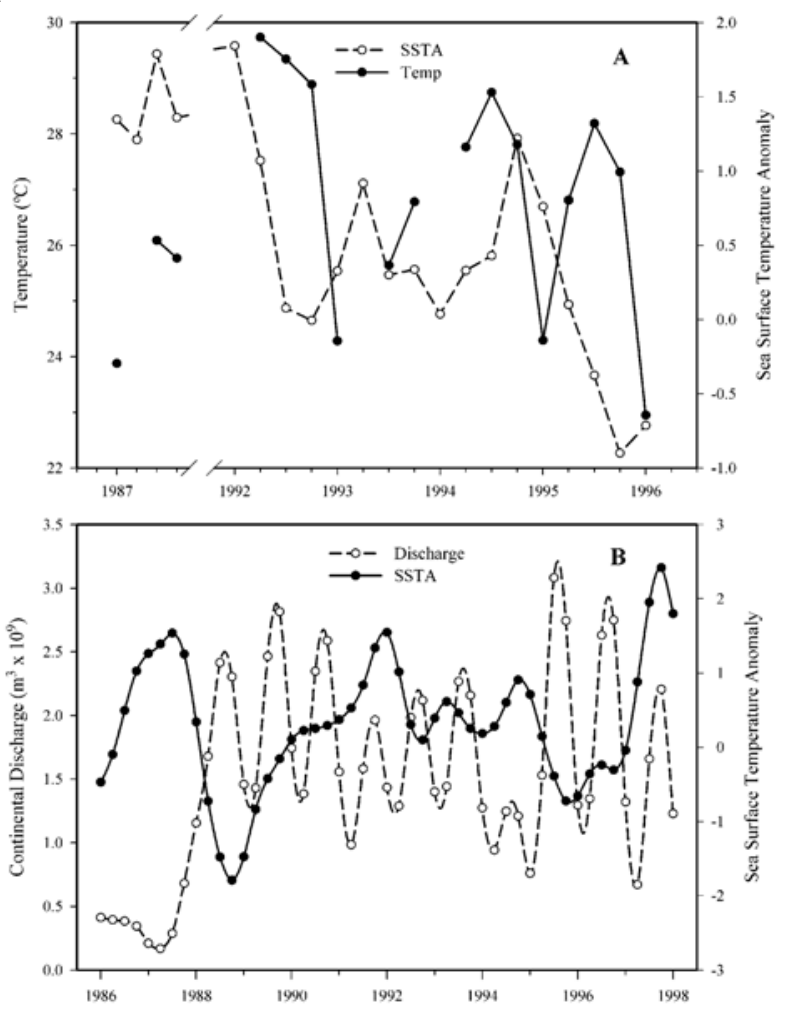

Figure 3

Surface average temperature (30 $\mathrm{m}$ depth) of the water column (A) and continental water discharges (B) in the southern Gulf of Mexico related to the sea surface temperature anomaly in the central equatorial Pacific, Region Niño 3.4

Promedio de la temperatura superficial (30 m de profundidad) de la columna de agua (A) y descargas de agua continental (B) en el sur del Golfo de México, relacionados con la anomalía de la temperatura superficial del mar en el

Océano Pacífico ecuatorial central, Región Niño 3.4

The above data showed lower values of temperature, discharge, and chlorophyll density and large larval densities of $B$. cantori during El Niño years and an inverse trend during normal years.

\section{Discussion}

The largest source of world inter-annual climate variability is El Niño-Southern Oscillation (ENSO) that extends globally through the ability of the atmosphere to bridge oceans basins (Karoly 1989, Wang et al. 2004). The manifestations of the changes in the atmospheric circulation in the tropics are detected throughout the global atmosphere by teleconnections (Trenberth et al. 1998). At the same time, changes in the atmospheric circulation can influence the oceans and force an 


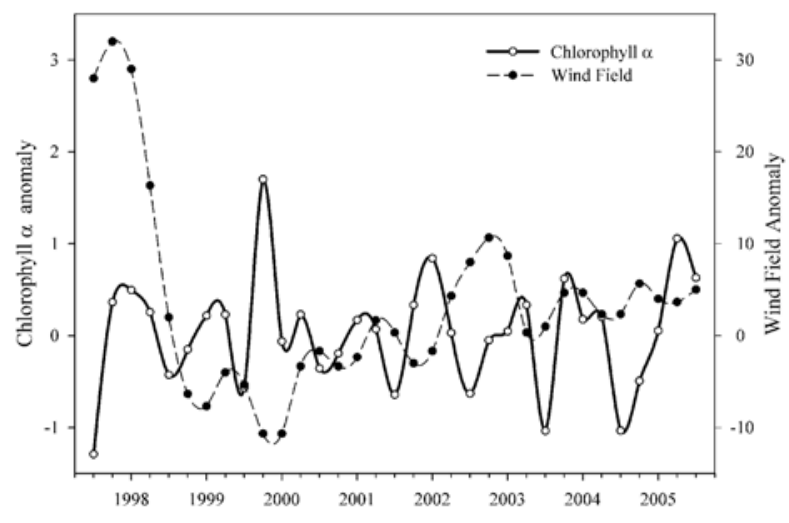

Figure 4

\section{Relationship between wind field and chlorophyll $a$ anomalies in the southern Gulf of Mexico}

Relación entre las anomalías del campo de vientos y clorofila $a$ en el sur del Golfo de México

identifiable signal (Wang et al. 2004). ENSO signals in the Gulf of Mexico are small (Mestas-Núñez \& Enfield 2005), but they can influence physical and biological aspects of the coast (Escobar-Briones 2002, García et al. 2003).

During the study period (1987-1996), there were three El Niño years, 1987, 1992, and 1995. Although some authors did not consider 1995 as an El Niño year, others did. For example, Magaña \& Morales (2004) considered that 1991-1995 was the longest El Niño period ever seen. Trenberth \& Hoar (1996) referred that the warm event related to El Niño in the tropical Pacific from 1990 to June 1995 was the longest period recorded since 1882; this was never seen in the climate record for the past 113 years. These ten-year data did not show any seasonal variation pattern of abundance for B. cantori larvae. High and low densities of this fish larva occurred in different seasons and different years (Fig. 2). High and low values alternated among seasons, except for 1992 when a sequence from high to low values occurred from winter to fall. These differences indicated that abundance variability might be determined by factors acting at time scales longer than one year.

The positive correlation between SSTA and larval abundance was more evident for El Niño years (Table 3). The largest larval densities occurred during El Niño years (1987, 1992, and 1995) and the lowest in the normal years indicated that El Niño events influenced positively the larval abundance, probably as a result of several factors interacting one another each other. Possibly, the influence was indirectly affecting the habitat conditions, particularly the temperature, continental water discharges and primary production, food availability that fish could use.
Low surface temperature in the Atlantic Ocean like those recorded during El Niño 1983 (Philander 1990) was shown in the results of 1987, 1992, and 1995. On the other hand, the low continental water discharges occurring during El Niño years corresponded to its general feature; that is, during El Niño there is less rain in areas which are normally rainy (Magaña \& Morales 2004).

The inverse relationship between chlorophyll anomaly in area studied and SSTA indicated that high biological production occurred during the normal years. Probably, there is some nutrients enrichment along with the high continental water discharges in such period. Generally, the largest biotic production in the southern Gulf of Mexico is a consequence of the nutrient enrichment through the continental water discharges, as it occurred in the northern Gulf of Mexico (Govoni et al. 1989, Cowan \& Shaw 1991, Biggs \& Sanchez 1997, Chen et al. 1997) and other parts of the world (Bowman \& Iverson 1978, Mann \& Lazier 1991).

Because larvae of $B$. cantori are first order carnivores that feed on plankton, copepods, and cladocers (ZavalaGracía \& Flores-Coto 1994), high larval density was expected during normal years when larger discharges and high temperatures generated larger biotic production (Vidal \& Whiteledge 1982, Davis 1987) from the primary production (high chlorophyll) and zooplankton biomass. As in other ecosystems high primary production is the most important item for larval fish survival (Platt et al. 2003). Nevertheless the results were the opposite, consequently the variability of $B$. cantori larvae must be related indirectly with El Niño events.

According to Bakun \& Broad (2003), globally teleconnected climatic trends or shifts might produce globally-coherent population expansions even when local environmental expression may be quite different, as in the case of adult sardine population that increased in the Eastern Pacific during El Niño periods. El Niño has positive and negative effects on different fish populations, such as the decreased population of anchovy (Engraulidae) in Peru, but increased populations of sardine (Clupeidae), jurel (Carangidae), and mackerel (Scombridae). In front of California in 1957-1958 and 1982-1983, El Niño diminished the fish shipments that formed large schools, but increased the capture of species of commercial value such as tunas (Scombridae), dolphins (Coryphaenidae), and barracudas (Sphyrenidae) (Arntz \& Fahrbach 1996).

Why did the largest larval densities occur during El Niño years, when the continental water discharges and biotic production are low? The answer could be related to the predator-prey relationship. 
It seems logical that abundance of $B$. cantori larvae must be proportional to the adult size population. If there was a large adult population, it probably represented an important food source for large predators' species like Lutjanidae, Scombridae and other pelagic fish. Some fish species, such as Lutjanus gutatus (Lutjanidae), Synodus foetens (Synodontidae), Campsodon snyderi (Campsodontidae), and Merluccius gayi (Merlucciidae), prey on Bregmacerotidae (Morohoshi \& Sasaki 2003, Rojas et al. 2004, Cruz-Escalona et al. 2005, Tam et al. 2006).

Changes in the diet of some population could occur when the main prey population disappear or decrease. During El Niño 1982-1983, in two locations of the Peruvian coast, the proportion of anchovy (Engraulis ringens) abundance in the diet of jack mackerel (Trachurus murphyi) was reduced, while the crustacean abundance increased (Arntz \& Fahrbach 1996). Merluccius gayi peruanus also fed mainly on anchovy and euphausids; however, because of tropicalization during the El Niño in 1997-1998, there was a reduction in anchovy consumption and a significant increase in consumption of other preys such as Myctophidae, and Bregmacerotidae (Tam et al. 2006). Thus, any fish population will move toward a more abundant and available prey.

In a normal food chain, during the normal years, where continental water discharges are high and biological productivity is enhanced, large predator fishes must have high food availability and may not need small species like B. cantori.

As a result of predator-prey oscillations or low pressure of predation, the stock of $B$. cantori must increase substantially. When the food availability for predators decreases during El Niño, small fish species like Bregmacerotidae become an important prey. Consequently, the adult population decays and the number of larvae decrease for the next generation.

From this study the main conclusions are that in the Southern Gulf of Mexico, the abundance of $B$. cantori larvae do not have a seasonal variation pattern, and that the variability is indirectly related with El Niño through of the habitat parameters as temperature, continental water discharges and food availability. According to the results of this study we propose the following hypothesis: The high and low larval densities of $B$. cantori during El Niño and normal years respectively are controlled by predatorprey relationships.

\section{Acknowledgments}

We express our thanks to the Dirección General de Personal Académico of the Universidad Nacional Autónoma de México for support of this study through Program IN202292. We also thank the crew of the R/V
'Justo Sierra' as well as the anonymous reviewers who helped to improve this paper.

\section{Literature cited}

Arntz WE \& E Fahrbach. 1996. El NIÑO Experimento climático de la naturaleza, 312 pp. Fondo de Cultura Económica, México.

Bailey KM \& IS Incze. 1985. El Niño and the early life history and recruitment of fishes in temperate marine waters. In: Wooster WS \& DL Fluharty (eds), El Niño north: Niño effects in the eastern subarctic Pacific Ocean, pp. 143-165. Washington Sea Grant Program Publication WSG-WO 853. University of Washington, Seattle.

Bakun A \& K Broad. 2003. Environmental 'loopholes’ and fish population dynamics: comparative pattern recognition with focus on El Niño effects in the Pacific. Fisheries Oceanography 12: 458-473.

Biggs DG \& LL Sanchez. 1997. Nutrient enhanced primary productivity of the Texas-Louisiana continental shelf. Journal of Marine Systems 11: 237-247.

Bowman MJ \& RL Iverson. 1978. Estuarine and plume fronts. In: Bowman MJ \& WE Esaias (eds), Oceanic Fronts in Coastal Processes, pp. 87-104. Springer-Verlag, Berlin.

Chavez FP, PG Strutton, GE Friederich, RA Feely, GC Feldman, DG Foley \& MJ McPhaden. 1999. Biological and chemical response of the equatorial Pacific ocean to the 1997-98 El Niño. Science 286: 2126-2131.

Chelton DB, PA Bernal \& JA McGowan. 1982. Large-scale interannual physical and biological interactions in the California Current. Journal of Marine Research 40: 1095-1125.

Chen CD, DA Wiesenburg \& L Xie. 1997. Influences of river discharges on biological production over the inner shelf: a coupled biological and physical model of the LouisianaTexas shelf. Journal of Marine Research 55: 293-320.

Cowan JH \& RF Shaw. 1991. Ichthyoplankton off west Louisiana in winter 1981-1982 and its relationships with zooplankton biomass. Contributions in Marine Science 32: 103-121.

Cruz-Escalona VH, MS Peterson, L Campos-Davila \& M Zetina-Rejón. 2005. Feeding habits and morphology of lizardfish (Synodus foetens) on the central continental shelf off Veracruz, Gulf of Mexico. Journal of Applied Ichthyology 21: 525-530.

Davis CS. 1987. Components of the zooplankton production cycle in the temperate ocean. Journal of Marine Research 45: 947-983.

Duffy D \& PJ Bryant. 1998. The 1997-1998 El Niño/Southern Oscillation (ENSO 97-98) One of the most severe ENSO events in history? University of California. WWW page, http://darwin.bio.uci.edu/sustain/ENSO.html.

Escobar-Briones E. 2002. The effect of the 1997-1998 ENSO on the benthic macrofaunal biomass in the southwestern Gulf of Mexico. Geofísica Internacional 42(3): 517-522.

Funes-Rodríguez R, C Flores-Coto, A Esquivel-Herrera, MA Fernández-Alamo \& A Gracia-Gasca. 2002. Larval 
fish community structure along the west coast of Baja California during and after El Niño event (1983). Bulletin of Marine Science 70: 41-54.

Garcia AM, JP Vieira \& KO Winemiller. 2003. Effects of 1997-1998 El Niño on the dynamics of the shallow-water fish assemblage of the Patos Lagoon Estuary (Brazil). Estuarine, Coastal and Shelf Science 57: 489-500.

Govoni JJ, DE Hoss \& DR Colby. 1989. The spatial distribution of larval fishes about the Mississippi River plume. Limnology and Oceanography 34: 178-187.

Houde ED. 1981. Distribution and abundance of four types of codlet (Pisces: Bregmacerotidae) larvae from the eastern Gulf of Mexico. Biological Oceanography 1: 81-104.

Houde ED. 1984. Bregmacerotidae: development and relationship. In: Moser HG, WJ Richards, DM Cohen, MP Fahay, AW Kendall \& SL Richardson (eds), Ontogeny and systematics of fishes. American Society of Ichthyology and Herpetology. Special Publication 1: 300-308.

Karoly DJ. 1989. Southern hemisphere circulation associated with El Niño-Southern Oscillation events. Journal of Climate 2: 1239-1252.

Lluch-Cota D, D Lluch-Belda, S Lluch-Cota, J LópezMartínez, M Narváez-Martínez, G Ponce-Díaz, G Salinas-Zavala, A Vega-Velazquez, JR Lara-Lara, G Hammann \& J Morales. 2004. Las pesquerías y El Niño. In: Magaña RV (ed), Los impactos de El Niño en México, pp. 137-178. UNAM, SEP-CONACyT, Mexico.

MacCall AD \& MH Prager. 1988. Historical changes in abundance of six fish species off Southern California, based on CalCOFI eggs and larva samples. California Cooperative Oceanic Fisheries Investigation 29: 91-101.

Magaña V \& C Morales. 2004. El clima y la sociedad. In: Magaña V (ed), Los impactos de El NIÑO en México, pp. 1-22. UNAM, SEP-CONACyT, Mexico.

Mann KH \& JR Lazier. 1991. Dynamics of marine ecosystems, 466 pp. Blackwell Science Publications, Boston.

McClain CR, M Cleave, G Feldman, W Gregg, S Hooker \& N Kuring. 1998. Science quality SeaWiFS data for global biosphere research. Sea Technology 39: 10-16.

Mestas-Nuñez AM \& DB Enfield. 2005. Potential climaticinduced changes in the Gulf of Mexico. U. S. GLOBEC Report 19: 1-2.

Miller CB, HP Batchelder, RD Brodeur \& WG Pearcy. 1985. Response of the zooplankton and ichthyoplankton off Oregon to El Niño event of 1983. In: Wooster WS, DL Fluharty (eds), El Niño north: Niño effects in the eastern subarctic Pacific Ocean. pp. 143-165. Washington Sea Grant Program Publication WSG-WO 85-3. University of Washington, Seattle.

Morohoshi Y \& K Sasaki. 2003. Intensive cannibalism and feeding on bregmacerotids in Champsodon snyderi (Champosodontidae): evidence for pelagic predation. Ichthyological Research 50: 387-390.
Moser HG, PE Smith \& LE Eber. 1987. Larval fish assemblages in the California Current region, 1954-1960. A period of dynamic environmental change. California Cooperative Oceanic Fisheries Investigations 28: 97-127.

Philander SG. 1990. El Niño, La Niña, and the southern oscillation, 293 pp. Academic Press, San Diego.

Platt T, C Fuentes-Yaco \& KT Frank. 2003. Spring algal bloom and larval fish survival. Nature 423: 398-399.

Richards WJ. 2006. Early stages of Atlantic fishes: An identification guide for the western central North Atlantic, 2640 pp. CRC Press, Boca Raton.

Roesler CS \& DB Chelton. 1987. Zooplankton variability in the California Current, 1951-1982. California Cooperative Oceanic Fisheries Investigations 28: 59-96.

Rojas JR, M Maravilla \& F Chicas. 2004. Hábitos alimentarios del pargo mancha Lutjanus guttatus (Pisces: Lutjanidae) en los Cóbanos y Puerto La Libertad, El Salvador. Revista de Biología Tropical 52: 163-170.

Schwing FB, T Murphree, L de Witt \& P Green. 2002. The evolution of oceanic and atmospheric anomalies in the Northeast Pacific during the El Niño and La Niña events of 1995-2001. Progress in Oceanography 54: 459-491.

Smith PE. 1985. A case history of Anti-El Niño to El Niño transition on plankton and nekton distribution and abundances. In: Wooster WS \& DL Fluharty (eds), El Niño north: Niño effects in the eastern subarctic Pacific Ocean, pp. 121-142. Washington Sea Grant Program Publication WSG-WO 85-3. University of Washington, Seattle.

Tam J, S Purca, LO Duarte, V Blaskovic \& P Espinoza. 2006. Changes in the diet of hake associated with El NIÑO 1997-1998 in the northern Humbolt Current ecosystem. Advances in Geosciences 6: 63-67.

Trenberth KE \& TJ Hoar. 1996. The 1990-1995. El NiñoSouthern Oscillation event: longest on record. Geophysical Research Letters 23: 57-60.

Trenberth KE, GW Branstator, D Karoly, A Kumar, NC Lau \& C Ropelewski. 1998. Progress during TOGA in understanding and modeling global teleconnections associated with tropical sea surface temperatures. Journal of Geophysical Research 103: 14291-14324.

Vidal J \& TE Whiteledge. 1982. Rates of metabolism of planktonic crustaceans as related to body weight and temperature of habitat. Journal Plankton Research 4: 77-84.

Wang C, SP Xie \& JA Carton. 2004. A global survey oceanatmosphere interaction and climate variability. In: Wang C, SP Xie \& JA Carton (eds), Earth's climate: The oceanatmosphere interaction. Geophysical Monograph Series 147: 1-19.

Zavala-García F \& C Flores-Coto. 1994. Abundancia y distribución de larvas de Bregmacerotidae (Pisces) en la Bahía de Campeche, México. Ciencias Marinas 20: 219-241.

Zar JH. 1996. Biostatistical Análisis, 662 pp. Prentice-Hall, New Jersey.

Recibido el 29 de octubre de 2007 y aceptado el 23 de enero de 2008 